\title{
Notes on some Late Cretaceous goniasterid starfish (Echinodermata, Asteroidea) from Belgium and Germany
}

\author{
Notas sobre algunas estrellas de mar goniastéridas (Echinodermata, Asteroidea) del \\ Cretácico tardío de Bélgica y Alemania
}

urn:Isid:zoobank.org:pub:39364C1 1-A75F-4BAA-B048-85AB51 EF7484

John W. M. Jagt ${ }^{1, *}$, Elena A. Jagt-Yazykova ${ }^{2}$, Barry W. M. Van Bakel ${ }^{3,4}$, René H. B. Fraaije ${ }^{4}$

${ }^{1}$ Natuurhistorisch Museum Maastricht, De
Bosquetplein 6-7, 6211 KJ Maastricht, Netherlands.

${ }^{2}$ Uniwersytet Opolski, Instytut Biologii, ul.

${ }^{3}$ Universiteit Utrecht, Faculteit Geowetenschappen, Budapestlaan 4, 3583 CD Utrecht, Netherlands.

${ }^{4}$ Oertijdmuseum, Bosscheweg 80, 5283 WB Boxtel, Netherlands.

* Corresponding author: (J.W.M. Jagt) john.jagt@maastricht.nl Oleska 22, 45-052 Opole, Poland.

\section{ABSTRACT}

Both partially articulated specimens and dissociated marginal ossicles form the basis for erection of two new species of Late Cretaceous goniasterids from the Mons and Liège-Limburg basins (Belgium) and the Hannover area (Germany). Chomataster breizh sp. nov., which recalls the type species, Chomataster acules Spencer, 1913, but differs in several respects, is based on a partial external mould of the marginal frame of disc and arms in flint (upper Campanian Spiennes Chalk Formation; Mons Basin), as well as on a more or less complete individual, preserving small, spherical spines and granules and encased in a flint nodule from the upper Maastrichtian Nekum Member (Maastricht Formation; Liège-Limburg Basin). In Ch. breizh sp. nov., supero- and inferomarginals bear close-set granule pits, of varying sizes, as well as bivalved alveolar scars of pedicellariae; median superomarginals and all inferomarginals lack large, crater-shaped spine pits - such are found only in the disc/arm transition and along the arms. Dissociated supero- and inferomarginal ossicles from the lower and upper Campanian of the Hannover area and the upper Campanian of northeast Belgium, previously recorded either as indeterminate astropectinids or as Nymphaster obtusus (Forbes, 1848) var. nov. and as Nymphaster sp., respectively, here are assigned to Nymphaster mudzborgh sp. nov. This species is characterised by a row of 3-5 large spine pits on the aboral and lateral surfaces of superomarginals; inferomarginals have an angular profile and a close cover of granule pits. Nymphaster tethysiensis Villier, 2001, from the upper Campanian of Landes (southwest France; Villier and Odin, 2001) appears best accommodated in Chomataster as well, because in the arm superomarginals alternate rather than meet over the mid-radial line.

Keywords:

Valvatida,

Maastrichtian,

Neoasteroidea, Campanian,

Universidad Nacional Autónoma de México.

This is an open access article under the CC BY-NC-SA license(https://creativecommons.org/licenses/by-nc-sa/4.0/)

\section{RESUMEN}

Los especimenes parcialmente articulados, así como los huesecillos marginales disociados sientan la base para establecer dos nuevas especies Goniasteridae del Cretácico tardío, provenientes de las cuencas de Mons y Liège-Limburg en Bélgica y del área de Hannover en Alemania. La especie Chomataster breizh sp. nov., que recuerda a la Chomataster acules (Spencer, 1913) pero difiere en varios aspectos, se basa en un molde externo parcial de la estructura marginal del disco y los brazos en sílex (Spiennes, cuenca de Mons, Formación de Tiza del Campaniano superior); así como un ejemplar más o menos completo con gránulos y espinas pequeñas y esféricas, encerrado dentro de un nódulo de sílex, el cual corresponde al miembro Nekum del Mastrichtiano superior (cuenta Liège-Limburg de la Formación Mastrichtiana). Los marginales supero e infero de la especie Ch. breizh sp. nov., tienen cavidades granulares cercanas y de diferentes tamaños, así como cicatrices alveolares en ambas valvas de los pedicellariae; los supero-marginales medianos y todos los infero carecen de cavidades espinales grandes en forma de cráter, las cuales solo se encuentran en la transición del disco al brazo y a lo largo de los brazos. Los huesecillos disociados de los supero e infero marginales corresponden al Campaniano inferior y superior del área de Hannover, y del Campaniano superior del noreste de Bélgica; éstos estaban previamente registrados como astropectínidos indeterminados: Nymphaster obtusus (Forbes, 1848) varnov., y como Nymphaster sp., respectivamente, aquí se asignan a Nymphaster mudzborgh sp. nov. Esta especie se caracteriza por tener una hilera entre 3-5 cavidades grandes en la columna vertebral de las superficies aboral y lateral de los supero-marginales; en cambio, los infero-marginales tienen un perfil angular y una cubierta cerrada de cavidades granulares. El espécimen Nymphaster tethysiensis (Villier, 2001) del Campaniano superior de Landes (suroeste de Francia; Villier y Odin, 2001) sugiere pertenecer al Chomataster porque también los supero-marginales del brazo se alternan, en vez de encontrarse sobre la línea radial media.

Palabras clave: Neoasteroidea, Valvatida, Campaniano, Maastrichtiano, Europa, especies nuevas. 


\section{Introduction}

To our fellow palaeocarcinologists, it may come as some surprise to learn that the late Gérard Breton, to whose memory the present paper is dedicated, actually obtained his doctoral degree on a detailed study of Jurassic and Cretaceous starfish (Echinodermata, Asteroidea) in the early 1990s (Breton, 1992b). In fact, he had already published a few influential papers on the subject during the previous decade (Breton, 1979, 1981, 1984, 1985, 1986, 1987, 1988a, b, 1992a). Following his PhD thesis, Breton continued his studies of late Mesozoic and Paleogene asteroids, which culminated in another series of papers (Néraudeau and Breton, 1993; Breton, 1995a, 1995b, 1996, 1997a, 1997b; Breton et al., 1994, 1995; Breton and Ferré, 1995; Breton and Decombe, 1997; Breton and Vizcaïno, 1997; Breton and Boullier, 2001; Villier et al., 2004; Breton and Néraudeau, 2008).

In Breton's work, it is demonstrated that in Late Cretaceous starfish assemblages across Europe, species of the genus Nymphaster Sladen, 1889 constitute a conspicuous element (Table 1). In fact, several lineages have now been documented, mostly from the white chalk facies of England, northern and southern France, northern Germany and Denmark (for details, see Gale, 1987b, 1989; Breton, 1992b; Jagt, 2000; Villier, 2001). It was Gale (1987b, pp. 153, 154), who argued that Late Cretaceous taxa previously placed in genera such as Calliderma Gray, 1847 and Chomataster Spencer, 1913, would, in fact, be better accommodated in the extant genus Nymphaster. We concur and adopt his generic diagnosis herein.

Gale's (1987b, p. 172) concept of Chomataster is also followed and modified here, contrary to the view expressed by some authors (see e.g., Villier, 2001) that this genus would better be relegated into the synonymy of Nymphaster. The present record of Ch. breizh sp. nov. from the upper Maastrichtian of northeast Belgium shows that superomarginals do not meet over the interradial axis, but alternate, unlike the situation in species of Nymphaster. The same holds true for the late Campanian Nymphaster tethysiensis Villier, 2001, which is here transferred to Chomataster, albeit with a query.

Having been originally described (Spencer, 1913) exclusively on the basis of isolated marginal ossicles from the upper lower Maastrichtian of Rügen (Baltic Sea, northeast Germany), Chomataster acules has remained an enigmatic taxon. The two partial, flint-preserved specimens from the Mons and Liège-Limburg basins recorded herein, allow the genus to be described in more detail and to corroborate some observations made by Gale (1987b, 1989; see also Jagt, 2000).

From the white chalk and marly chalk facies ('Schreibkreide' and 'Mergelkalk' in German) of southern England, northern France and northern Germany, articulated material has been recorded of a number of species of Nymphaster, occasionally even illustrating various growth stages. Isolated marginal ossicles that clearly belong to this genus are available from the lower and upper Campanian of the Hannover area (Germany) and the LiègeLimburg Basin (Belgium). These, previously recorded either as indeterminate astropectinids or as $\mathcal{N}$. obtusus (Forbes, 1848) var. nov. (see Helm and Frerichs, 2013; Neumann et al., 2021) and as Nymphaster sp. (see Jagt, 2000), respectively, consistently differ from typical forms of $\mathcal{N}$. obtusus from the Santonian-lower Campanian of southern England, northern Germany (Lägerdorf, some $50 \mathrm{~km}$ north of Hamburg) and France in having 3-4 enlarged spine bases on aboral and lateral surfaces of superomarginals, arranged in distinct rows. This form is here described as a new species, Nymphaster mudzborgh sp. nov.

\section{Geographical and stratigraphical provenance}

One of the present specimens, the holotype of Chomataster breizh sp. nov. (NHMM 2020 009a, 009b; ex Ludo Indeherberge Collection, no. IL S1108), is preserved as a partial external mould in a fragment of a light grey flint nodule with a thin patina. It was collected from a field south 
Table 1. Extinct species and subspecies of the genera Chomataster Spencer, 1913 and Nymphaster Sladen, 1889, arranged alphabetically (data from Gale, 1987b; Breton, 1992b; Breton and Vizcaïno, 1997; Jagt, 2000; Villier, 2001; Andrew et al., 2015; Niebuhr and Seibertz, 2016), in addition to three other doubtful representatives (marked by ?).

\begin{tabular}{|c|c|}
\hline Ch. acules Spencer, 1913 & $\begin{array}{l}\text { upper lower Campanian-upper Danian; England, } \\
\text { Belgium, the Netherlands, Germany, Poland, Denmark }\end{array}$ \\
\hline Ch. breizh sp. nov. & $\begin{array}{l}\text { upper upper Campanian-upper upper Maastrichtian; } \\
\text { Belgium }\end{array}$ \\
\hline Ch. tethysiensis (Villier, 2001) & upper Campanian; France \\
\hline N. albensis (Geinitz, 1872) & middle Turonian-lower Coniacian; Germany \\
\hline N. alseni (Schulz and Weitschat, 1971) & upper Campanian; Germany, France, Belgium \\
\hline N. coombii (Forbes, 1848) & $\begin{array}{l}\text { upper Cenomanian-Santonian; France, England, } \\
\text { Germany }\end{array}$ \\
\hline N. fontis Breton and Vizcaïno, 1997 & Lower Eocene; France \\
\hline $\begin{array}{l}\text { N. h. humilis (Schulz and Weitschat, 1975) } \\
\text { (= Ch. rectus Schulz and Weitschat, } 1975\end{array}$ & Santonian-lower Campanian; England, German \\
\hline N. h. praehumilis (Breton, 1979) & Coniacian; France \\
\hline N. lymensis Gale, in Andrew et al., 2015 & Albian; England \\
\hline N. magistrorum (Breton, 1988) & middle Cenomanian-lower Turonian; France \\
\hline N. marginatus (Sladen, 1891) & lower Santonian; England \\
\hline N. obtusus (Forbes, 1848) & $\begin{array}{l}\text { middle Turonian-lower Campanian; England, } \\
\text { Germany, France }\end{array}$ \\
\hline $\begin{array}{l}\text { N. ornatus s. str. (Schulz and Weitschat, } \\
1975 \text { ) }\end{array}$ & upper Santonian; Germany \\
\hline N. ornatus cottardi (Breton, 1988) & lower Santonian; France \\
\hline N. peakei Gale, 1987 & upper upper Campanian; England?, France \\
\hline N. spenceri (Wienberg Rasmussen, 1950) & $\begin{array}{l}\text { lower-upper Maastrichtian, Denmark, Germany, the } \\
\text { Netherlands }\end{array}$ \\
\hline $\begin{array}{l}\text { N. studlandensis (Schulz and Weitschat, } \\
\text { 1975) }\end{array}$ & $\begin{array}{l}\text { lower upper Campanian; Germany, Belgium, England, } \\
\text { the Netherlands }\end{array}$ \\
\hline N. mudzborgh sp. nov. & lower-upper Campanian; Germany, Belgium \\
\hline N. wrighti (Wienberg Rasmussen, 1950) & upper Maastrichtian; Denmark, the Netherlands \\
\hline N.? arduennensis (Peron, 1887) & lower Albian; France \\
\hline N.? dolmeni Breton, 1992b & Turonian; France \\
\hline N.? dutempleaus (d'Orbigny, 1850) & Albian; France \\
\hline
\end{tabular}

of the village of Spiennes (Mons Basin, southern Belgium) which is locally known as the 'Camp-àCayaux' (no. 1 in Figure 1B), since the late 1980s. This archaeological site has now gained UNESCOstatus and is thus protected, precluding additional collecting of fossiliferous flint nodules and flakes. The 'Camp-à-Cayaux' and a nearby site at PetitSpiennes are renowned for their prehistoric flints tools (McNamara, 2011). In Neolithic times, there were underground galleries in the area from which flint nodules were extracted, brought to the surface and then knapped. In those galleries, as well as in an outcrop along the railway tracks, a number of flint levels are exposed (L. Indeherberge, pers. comm., November 2020), but the present asteroid specimen from the field cannot be linked to any of these with certainty. However, all flint bands are situated within the Spiennes Chalk Formation (Table 2), which on cephalopod (coleoid, ammonoid), brachiopod and benthic foraminiferal evidence, has been shown to be of late late Campanian age (Robaszynski and Christensen, 1989; Kennedy, 1993; Christensen, 1999; Simon, 2000; Simon and Owen, 2001; Robaszynski et al., 2002; Keutgen, 2011). 
Christensen (1999, fig. 2) correlated the 'Craie de Spiennes' (= Spiennes Chalk Formation, in current terminology) with the upper polyplocum, langei and grimmensis/granulosus zones of the standard zonation for northwest Germany (Table 3), on the basis of the section exposed at the Harmignies CGC chalk pit, only a few hundred metres to the southeast of the 'Camp-à-Cayaux' field. The index coleoid species is Belemnitella minor I Jeletzky, 1951, in particular in the lower 10 metres of the Spiennes Chalk Formation, which allows this unit to be correlated with the Beeston Chalk of Norfolk (England; Christensen, 1995) and the Beutenaken Member (Gulpen Formation) in southern Limburg (the Netherlands; see Keutgen, 2011).

Flint nodules collected in the late 1980s and 1990s from the 'Camp-à-Cayaux' by Ludo Indeherberge, Roland Meuris and Edwin Defour, have also yielded irregular echinoids of correlative value, including Cardiaster cordiformis (Woodward, 1833) and Micraster ciplyensis Schlüter, 1897. The former is known from correlative upper Campanian levels (polyplocum Zone equivalents; Table 3) in southeast England (Norfolk) and the Hannover area, Germany (Ernst, 1972; Niebuhr et al., 1997; Smith and Wright, 2003). Interpretation of the latter echinoid taxon is still fraught with difficulties, not in the least since the present whereabouts of the type specimen, an internal flint mould, are unknown. On the basis of newly collected material from the Spiennes area, Indeherberge et al. (1999) considered M. ciplyensis to be a late late Campanian offshoot of the schroederi/glyphus lineage, but this view can no longer be upheld.

Stokes (1975) interpreted it as a possible variety of 'Isomicraster' stolleyi (Lambert, in de Grossouvre, 1901), a view subsequently adopted by Smith and Wright (2012; as Micraster (Gibbaster) stolleyi), with

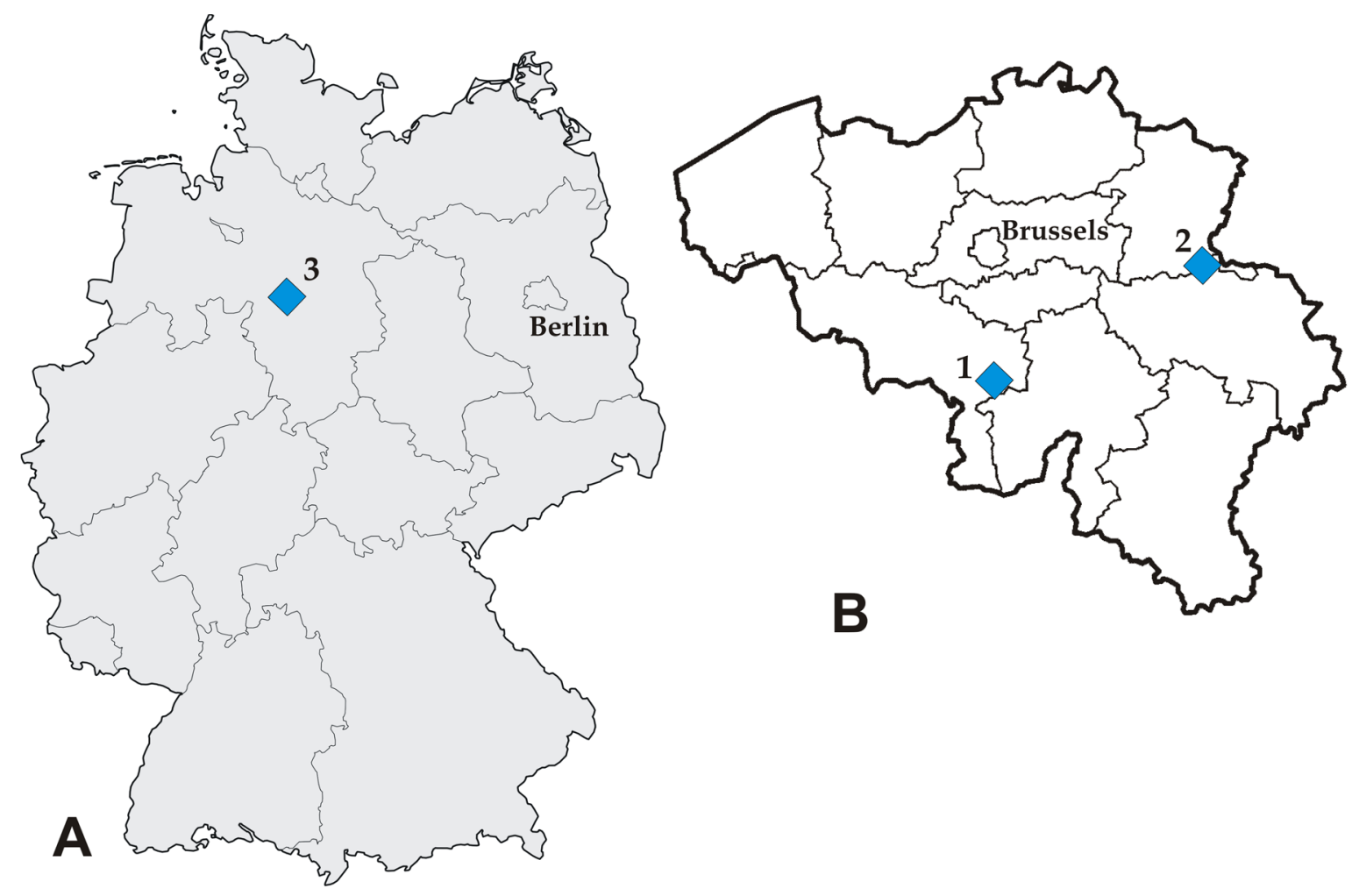

Figure 1 Schematic map of Germany $(A)$ and Belgium $(B)$, showing the provenance areas of material of Chomataster breizh sp. nov. and Nymphaster mudzborgh sp. nov. recorded herein: 1. Camp-à-Cayaux, near Spiennes, province of Hainaut (Mons Basin); 2. CBRRomontbos quarry, Eben Emael-Bassenge, province of Liège (Liège-Limburg Basin); 3. Holcim-Höver and Teutonia (HeidelbergCement) quarries, Höver and Misburg-Anderten (Hannover area). 
Table 2. Lithostratigraphy of upper Upper Cretaceous (CampanianMaastrichtian) strata in the Mons Basin (after Robaszynski et al., 2002).

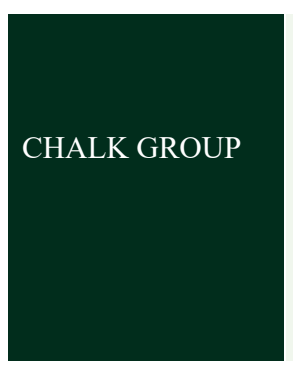

Saint-Symphorien Calcarenite Formation

Ciply-Malogne Phosphatic Chalk Formation

Spiennes Chalk Formation

Nouvelles Chalk Formation

Obourg Chalk Formation

Trivières Chalk Formation

reference to material described and illustrated by Lambert (1911). Naturally, this interpretation, if adhered to, would require suppression of the species name ciplyensis of Schlüter (1897). This matter will be discussed in detail in a forthcoming paper.

The other flint-preserved specimen (paratype of Chomataster breizh sp. nov.; NHMM Van Rijsselt Collection, no. 100) originates from the lower Nekum Member (Maastricht Formation; Table 4) at the CBR-Romontbos quarry (no. 2 in Figure 1B) near Eben Emael (Bassenge, province of Liège). On the basis of cephalopods, inoceramid bivalves and palynomorphs this part of the section can be dated as late late Maastrichtian (Keutgen, 2011, 2018; Jagt and Jagt-Yazykova, 2012, 2018).

Finally, dissociated marginal ossicles of Nymphaster mudzborgh sp. nov. are from the lower Campanian (pilula and pilula/senonensis zones) and upper Campanian (vulgaris Zone [= vulgaris/basiplana Zone, vulgaris/stolleyi Zone] at the Holcim-Höver and Misburg-Anderten (HeidelbergCement) quarries, respectively (the Hannover area, Lower Saxony, Germany; no. 3 in Figure 1A). Added is another example from the upper lower Campanian Zeven Wegen Member (Gulpen Formation) at Haccourt, province of Liège, Belgium (Jagt, 1999, 2000).

Abbreviations: NHMM - Natuurhistorisch Museum Maastricht, Maastricht, the Netherlands; NHMUK - The Natural History Museum, London, United Kingdom; r - minor radius; R - major radius; IM(s) - inferomarginal ossicle(s); $\mathrm{SM}(\mathrm{s})$ - superomarginal ossicle(s) (terminology following Gale, 1987a).

\section{Systematic palaeontology}

\author{
Class Asteroidea de Blainville, 1830 \\ Subclass Neoasteroidea Gale, 1987c \\ Superorder Surculifera Gale, 1987c \\ Order Valvatida Perrier, 1884 \\ Family Goniasteridae Forbes, 1841 \\ Genus Chomataster Spencer, 1913 emend.
}

Type species: Chomataster acules Spencer, 1913, by original designation (Spencer, 1913, p. 128).

Remarks: Following the original description of the genus (Spencer, 1913), it appears that all subsequent authors have accepted that the holotype of the type species, Ch. acules, was a median/ interradial SM and that all SMs of disc and arms had a single, large, crater-shaped spine pit, like in Spencer's reconstruction (1913, pl. 12, fig. 31). Gale (1987b, p. 172) gave the following diagnosis, 'Genus only known from isolated marginal ossicles; median superomarginals, tall, narrow, lateral face vertical; single large crater-shaped spine pit at summit of lateral face; inferomarginals possess broad, rounded oral surface, intermarginal facet narrow, 3-5 large crater-shaped pits on oral face.' Thus, the genus can be stated to lack enlarged, wedge-shaped (cuneate) SMs above the arm base that characterise several Late Cretaceous species of Nymphaster. A number of authors have also demonstrated that IMs of Ch. acules bear spine pits; occasionally just one, but mostly several (2-5) (see Schulz and Weitschat, 1975, pl. 31, figs 8, 9; Gale, 1987b, pl. 5, fig. 16a, b; Jagt, 2000, pl. 14, figs $3,4,9,11)$.

Gale (1987a, p. 172) noted that Chomataster was a poorly known genus, with an unknown ancestry; however, by assembling dissociated ossicles, it could be deduced to have had a broad and evenly rounded interradius and long, slender arms. He also postulated that the large, crater-shaped spine pits bore spherical spines. On the basis of articulated material, the new species described below corroborates Gale's (1987) interpretation and allows the generic diagnosis to be modified. 
Table 3. Standard biozonal scheme of Campanian-Maastrichtian strata in northwest Germany.

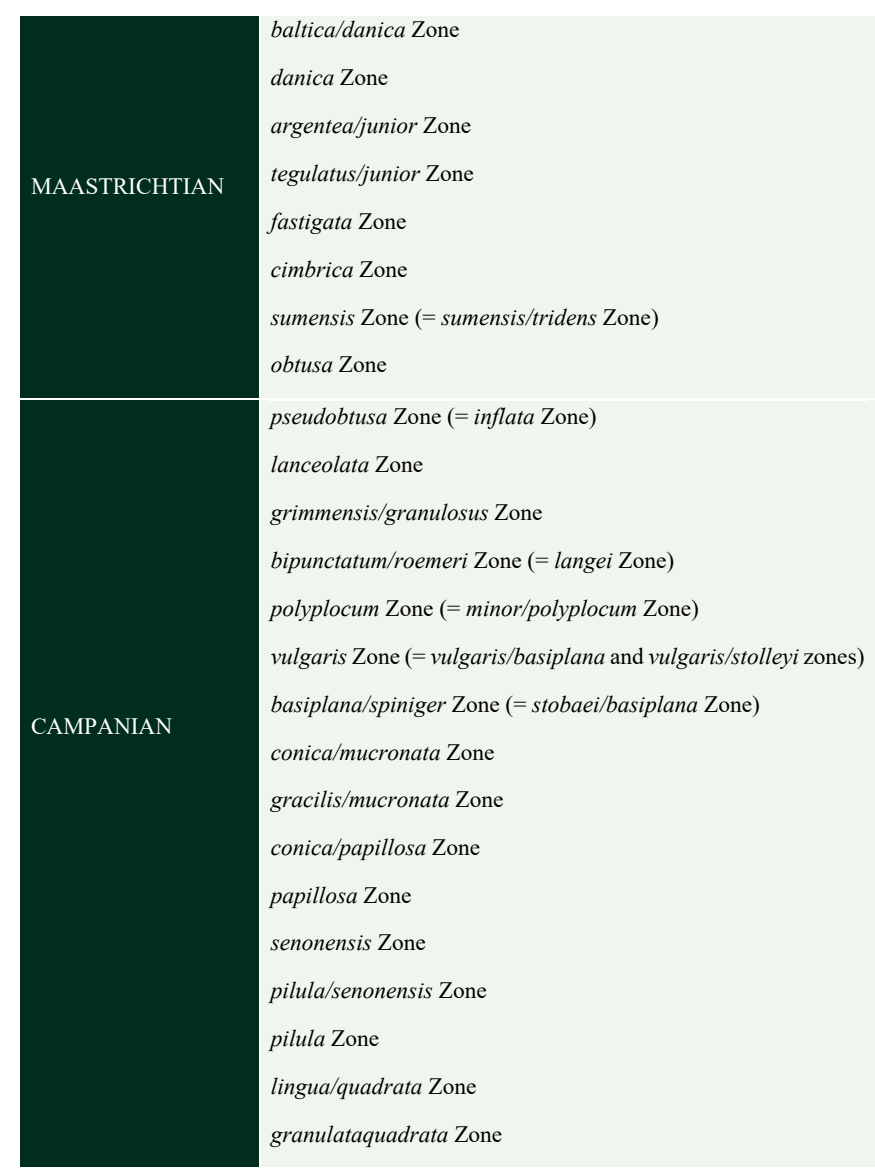

Diagnosis: Medium- to large-sized ( $\mathrm{R}$ up to $115 \mathrm{~mm}$; r up to $45 \mathrm{~mm}$ ) goniasterid with tall marginal ossicles; median/interradial superomarginals tall, narrow, lateral face either vertical, inclined outwards or evenly rounded to aboral surface; either with single large crater-shaped spine pit at the summit of the lateral face of all SMs, or only on those of disc/arm transition and along arms; in one species, two spine pits on distal SMs; spherical spines on SMs; no enlarged, 'angle' SMs at arm base; SMs in arms alternating, not opposing at mid-radial line; IMs with broad, rounded oral surface, intermarginal facet narrow, either merely with close-set granule cover or 1-5 large crater-shaped pits on oral face.

Species included: In addition to the type species, Ch. breizh sp. nov. and, possibly, Nymphaster tethysiensis Villier, 2001 (see below).
Chomataster acules Spencer, 1913

Chomataster acules Spencer (1913), p. 128, pl. 12, figs 28, 31; pl. 16, figs 8-13.

Chomataster acules, Spencer; Brünnich Nielsen (1943), p. 59, text-fig. 12a, b.

Chomataster brünnichi Wienberg Rasmussen (1945), p. 422, pl. 9, figs 10, 11 .

Chomataster acules Spencer; Wienberg Rasmussen (1950), p. 79, text-fig. 6e; pl. 10, fig. 12.

Chomataster acules Spencer; Müller (1953), p. 59,

$$
\text { pl. 7, figs } \mathrm{QQ}_{1-3} \text {. }
$$

Chomataster sp.; Maryańska and Popiel-Barczyk (1969), p. 132, pl. 2, fig. 6.

Chomataster acules Spencer 1913; Schulz and

Weitschat (1971), p. 119, pl. 25, fig. 19.

Chomataster acules Spencer, 1913; Schulz and

Weitschat (1975), p. 279, pl. 31, fig. 10.

Chomataster n. sp. aff. acules; Schulz and Weitschat

(1975), p. 280, pl. 31, figs 8, 9.

Chomataster acules Spencer 1913; Gale (1987b), p.

174, pl. 5, figs 15, 16.

Chomataster acules Spencer, 1913; Jagt et al. (1994), p. 318.

Chomataster acules Spencer, 1913; Jagt (2000), p. 418, pl. 14.

Chomataster acules Spencer, 1913; Reich and Frenzel (2002), p. 182.

Types: The holotype is NHMUK E 13255, an isolated median SM; paratypes are NHMUK E 13256-13262 (see Gale, 1987b; Lewis, 1993).

Type locality and horizon: Isle of Rügen (Baltic Sea, northeast Germany); upper lower Maastrichtian, sumensis to fastigata belemnite zones (Reich and Frenzel, 2002).

Discussion: Chomataster acules, as here interpreted, is a fairly long-ranging form, with the first records being from the lower upper Campanian (equivalents of the basiplana/spiniger and vulgaris zones of the German zonation; Table 3). The species extends into the upper Danian (Lower Paleocene) of Denmark. In the Liège-Limburg Basin (no. 2 in Figure 1B), it is known from the Zeven Wegen, Vijlen and Lanaye members 
Table 4. Lithostratigraphy of upper Upper Cretaceous (Campanian-Maastrichtian) strata in the Liège-Limburg Basin (after Robaszynski et al., 2002).

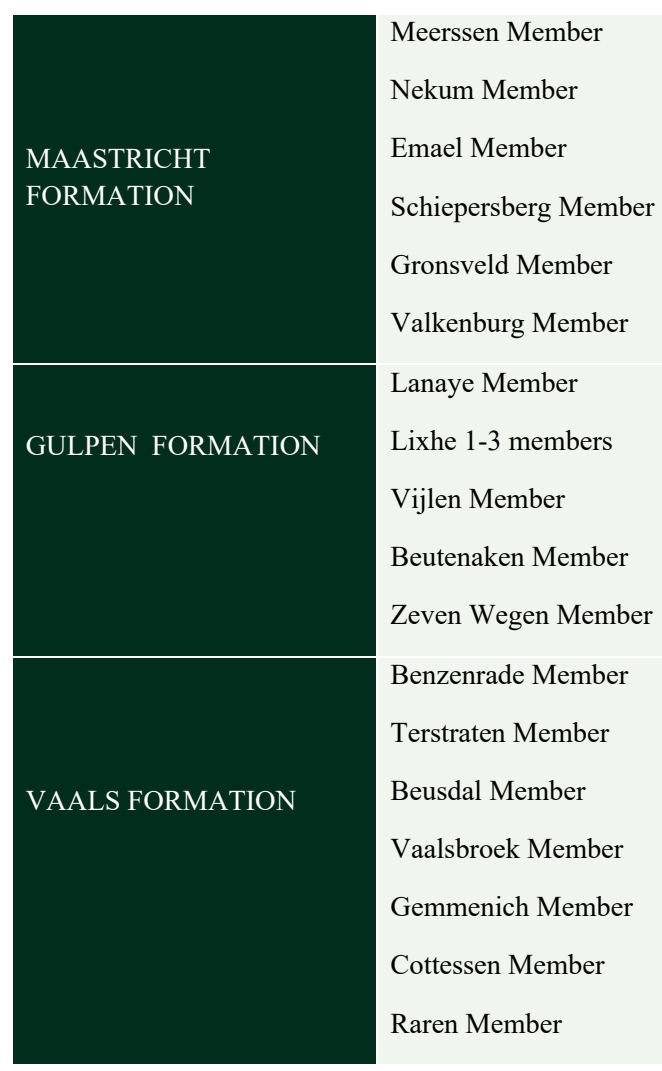

(all Gulpen Formation) and the Valkenburg, Gronsveld, Emael and Nekum members (all Maastricht Formation) (see Table 4). In the Nekum Member, there may thus be a range overlap with Ch. breizh sp. nov. (see below).

\section{Chomataster breizh sp. nov.}

Figures 2-6

urn:1sid:zoobank.org:act:D7D48F95-E5A9-49838A26-F9008967B10D

Chomataster acules Spencer, 1913; Jagt (2002), p. 12. Chomataster acules Spencer, 1913; Jagt (2010), p. 57. Chomataster acules Spencer, 1913; Jagt (2015), p. 135.

Chomataster acules Spencer, 1913; Jagt et al. (2018), pp. 266, 274, fig. 23A, B.

Types: The holotype is NHMM 2020 009a (ex Ludo Indeherberge Collection, no. IL S1 108),
NHMM 2020 009b is a silicone rubber cast of this imprint; the paratype is NHMM Van Rijsselt Collection, no. 100.

Type locality and horizon: 'Camp-àCayaux' near Spiennes (Mons Basin, southern Belgium); Spiennes Chalk Formation, but the exact level is unknown (upper upper Campanian, Belemnitella minor I Zone).

Derivation of name: 'Breizh' (pronounced [bьсjs] or [bьعх]), here used as a noun in apposition, is the name of Bretagne (Brittany) in the Breton (Celtic) language, in reference to the late Gérard Breton (https://en.wikipedia.org/wiki/ Brittany; accessed February 24, 2021).

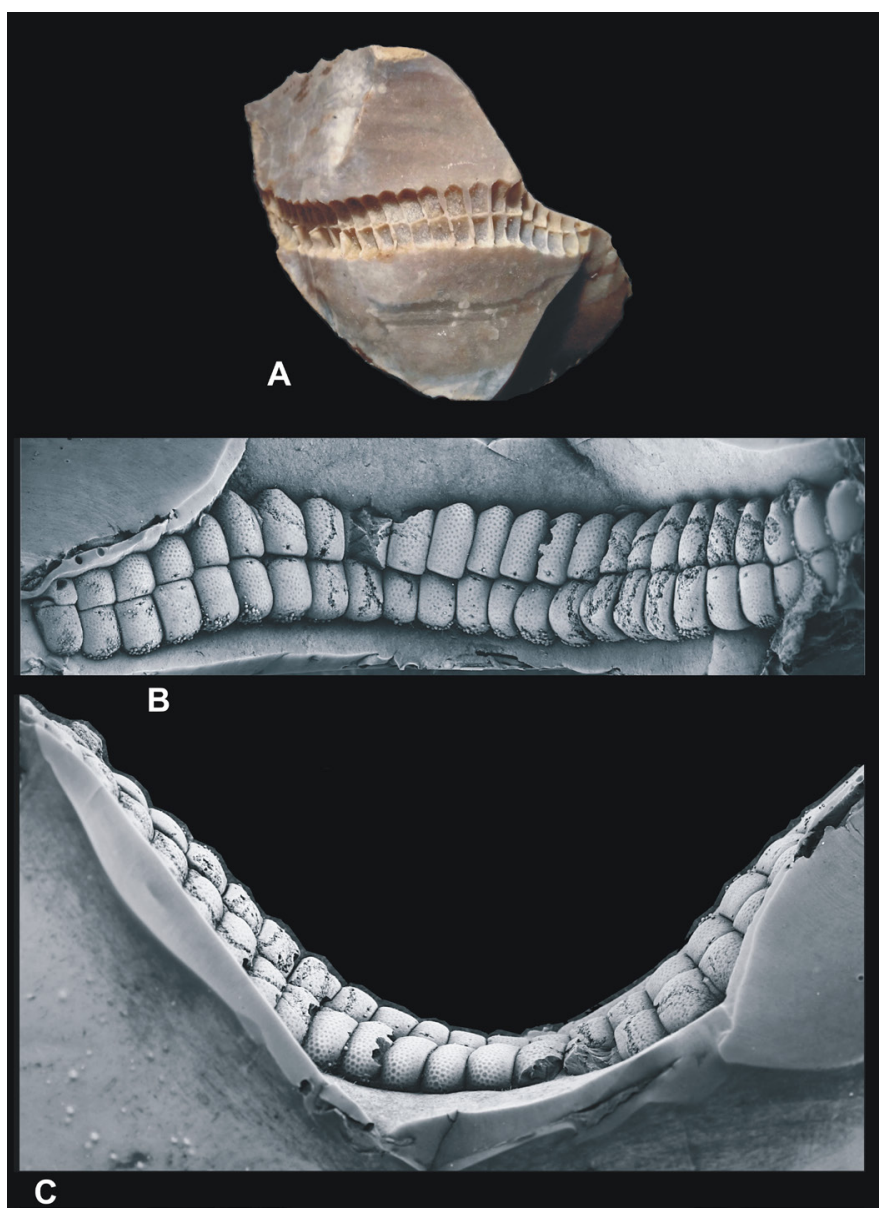

Figure 2 Chomataster breizh sp. nov. (holotype, NHMM 2020 009a), from the Camp-à-Cayaux, near Spiennes. A. External mould in a light-grey flint nodule of the marginal frame of disc and two arms (greatest width $65 \mathrm{~mm}$ ); $B-C$. Silicone rubber cast (NHMM 2020 009b) of the same, in lateral and aboral aspect; cast whitened with ammonium chloride sublimate prior to photography (photographs: B.W.M. van Bakel). In C, the broad, evenly rounded interradius is seen (aboral view). 
Diagnosis: Species of Chomataster with tall SMs and IMs; median SMs (SM1-5) narrower than others and lacking large, crater-shaped spine pits, but evenly rounded from lateral to aboral surface, covered in granule pits; from SM6 onwards, distal SMs with single, crater-shaped spine pit at summit of lateral face; all SMs and IMs with bivalved alveolar scars of pedicellariae, invariably close to intermarginal contact line; IMs with broadly rounded lateral face and slightly flattened aboral surface; lacking large spine pits throughout and only with close-set granules. No other ossicle types preserved.

Description of holotype: External mould of disc margin and two partial arms in a flint nodule; $24 \mathrm{SMs}$ and $23 \mathrm{IMs}$ are preserved (Figure $2 \mathrm{~A}$ and $2 \mathrm{~B}$ ). Interradius (Figure $2 \mathrm{C}$ ) broad and evenly rounded; no 'angle' SM at transition disc/ arms seen. Marginal ossicles tall, with more or less flat lateral face, but slightly swollen aboral surface and all with bivalved alveolar scars of pedicellariae (Figures 2B, 3A-C). Median SMs (SM1-5) slightly narrower than others (Figures 2B, 3A) and lacking large, crater-shaped spine pit; only even cover of granule pits. From SM 6 onwards, SMs have single crater-shaped spine pit (Figures 2B, $3 \mathrm{~B})$, positioned either centrally or more distally on aboral surface; flat articular facet for spines. IMs (Figures 2B, 3A-C) with broadly rounded lateral face, angular transition into slightly flattened aboral surface; lacking large spine pits throughout and only with close-set granules and all with bivalved alveolar scars of pedicellariae. No other ossicle types preserved.

Paratype additions: Near-complete disc ( $\mathrm{R}-$ c. $112 \mathrm{~mm} ; \mathrm{r}-$ c. $42 \mathrm{~mm}$ ); with three arms preserved (Figures 4-6), encased in flint nodule but with one arm exposed and well preserved, with complete spine and granule canopy (Figure 5A-D); five median SM-IM (possibly SM1-5) preserved (Figure 5A-B) and at least 13 distal SMs and IMs. From SM6 onwards, all distal SMs have a small, spherical spine (Figures 4-5). SMs alternate in $\operatorname{arm}($ Figure $5 \mathrm{~B}-\mathrm{C})$. Broken arm tip reveals stout adambulacral ossicles (Figure 5D). Granule cover of all marginal ossicles is close but its details are hidden by syntaxial calcite (see Neugebauer and Ruhrmann, 1978), as typical in coarse-grained biocalcarenites of the upper Maastricht Formation. Preliminary CT scans (Figure 6) suggest the disc and mouth frame to be well preserved; additional work and higher-resolution scanning are needed to obtain a $3 \mathrm{D}$ print of this specimen.

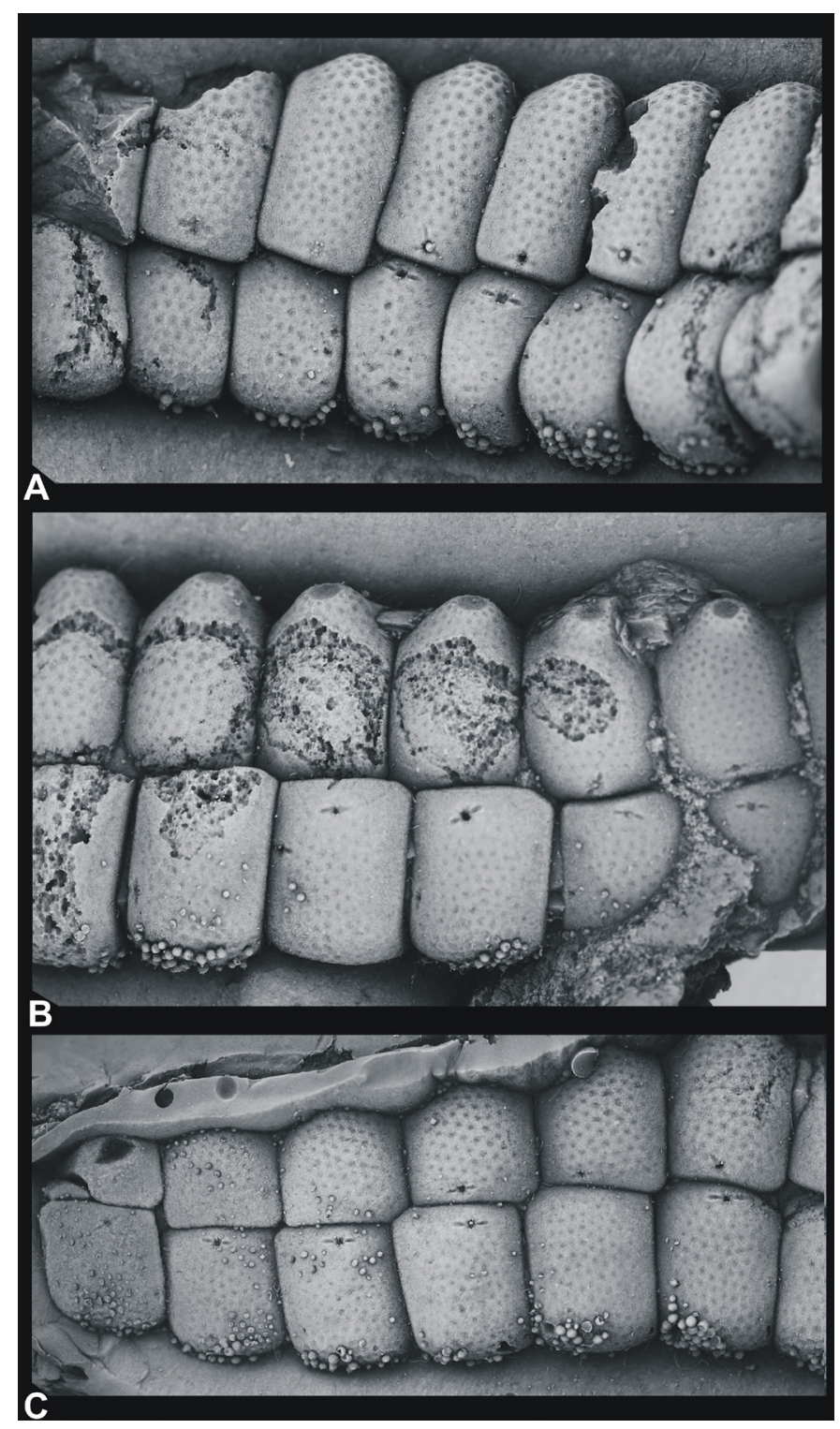

Figure 3 Chomataster breizh sp. nov. (holotype, NHMM 2020 009a), from the Camp-à-Cayaux, near Spiennes (see also Figure 2). $A-C$, illustrate marginal ornament of granule pits, bivalved alveolar scars of pedicellariae and large, crater-shaped spine pits on distal superomarginals (from SM 6), as well as preserved granules on inferomarginals. Cast whitened with ammonium chloride sublimate prior to photography (photographs: B.W.M. van Bakel). Width of images A-C: $22 \mathrm{~mm}$. 
Discussion: From the moment of discovery of the paratype of the new species, this was deemed to be the first articulated find of Chomataster acules and presented as such (see Jagt, 2002, 2010, 2015; Jagt et al., 2018), but the fact that it was encased in a flint nodule presented technical/preparatory challenges. A direct comparison with the holotype (Figures 2-3) has now shown these two specimens to be conspecific and of comparable size and to differ in several respects from what is known for $C h$. acules. The reason for selecting the external mould in flint from the 'Camp-à-Cayaux' as the holotype is that this shows the ornament and arrangement of marginal ossicles better than the paratype. Both specimens show Gale (1987b) to have been right in assuming the interradius to have been broad and evenly rounded and the spines to have been spherical.

The lack of large, crater-shaped spine pits on median SMs and on all IMs, distinguishes $C h$. breizh sp. nov. from $C h$. acules; lateral surfaces of SMs are more swollen on the transition into the aboral surface and are certainly not inclined outwards or slanting, as is often the case for SMs of Ch. acules. Nymphaster tethysiensis Villier, 2001, here transferred to Chomataster, albeit with a query, is easily distinguished from Ch. breizh sp. nov. in having stouter marginal ossicles with evenly rounded lateral and aboral surfaces and two spine pits on distal SMs.

From the upper lower and upper Campanian of southern England and northern Germany, Gale (1987b, pp. 168, 169; 1989, pp. 285-287, fig. 6), described a distinctive group of species of Nymphaster with straight interradii, four marginal ossicles in each interradius and an 'angle' SM at the disc/arm junction. The oldest is $\mathcal{N}$. studlandensis (Schulz and Weitschat, 1975), followed by $\mathcal{N}$. alseni (Schulz and Weitschat, 1971) with enlarged 'angle' ossicles and by $\mathcal{N}$. peakei (Gale, 1987b) with a tendency for spine pits to extend, from the arms, onto the interradial marginal plates. The members of this lineage are valuable index taxa that have subsequently also been recorded from the Liège-Limburg Basin (Jagt, 2000), with the excep- tion of $\mathcal{N}$. peakei due to a stratigraphical hiatus. In the genus Chomataster, the reverse appears to have taken place, with large spine pits confined to SMs in the arms in both Ch. breizh sp. nov. and Ch. tethysiensis and interradial SMs and all IMs exclusively with granule pits.

Occurrence: To date, Ch. breizh sp. nov. is known only from these two articulated finds, but a re-examination of material previously assigned to Ch. acules, and median SMs and all IMs in particular, should fill the stratigraphical gap and determine whether or not species also survived the Cretaceous-Paleogene (K/Pg) extinction event. In the Liège-Limburg Basin, both species appear to overlap in the Nekum Member (Maastricht Formation).

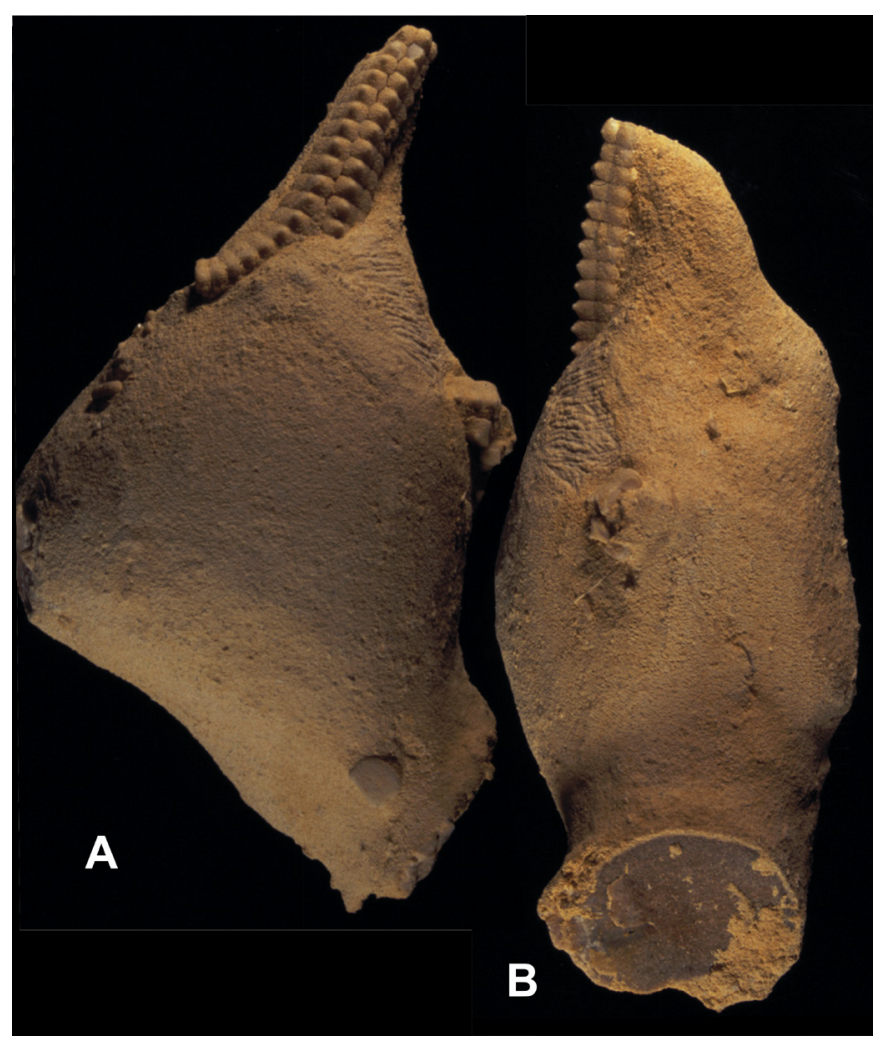

Figure 4 Chomataster breizh sp. nov. (paratype, NHMM van Rijsselt Collection, no. 100) from the lower Nekum Member (Maastricht Formation) at Eben Emael (CBR-Romontbos quarry); $x$ 0.5. $A, B$. upper and lateral upper views of flint nodule encasing specimen, with one arm sticking out. Specimen not whitened (photographs: R.W. Dortangs). In $A$, the broad, evenly rounded interradius is seen; button-like, spherical spines on superomarginals in $A$ and $B$. 
Chomataster tethysiensis (Villier, 2001) comb. nov.

Nymphaster tethysiensis Villier (2001), p. 586, fig. 3/1-20. Nymphaster tethysiensis; Villier and Odin (2001), p. 571, pl. I, figs 1-3, 5 .

Types: The holotype is AST IV 104,3; paratypes are AST II 81,4; AST IV 98,4; AST IV 98,7; ASI II 100,3; AST IV 104,3 [sic] and AST II 60,6 (present whereabouts unknown).

Type locality and horizon: Tercis les Bains quarry, Landes (southwest France), upper Campanian.

Diagnosis: 'Les supéromarginales de la base du bras portent généralement deux tubercules cratériformes pour l'articulation d'épines. Si leur position varie, il en existe systématiquement un sur le bord abactino-abradial. Vers l'extrémité du bras, ces tubercules passent à de simples protubérances arrondies et sur le disque, les marginales interradiales ne sont plus ornée que de f.a.e. Le centre de la face externe des supéromarginales se bombe légèrement et porte des fa.e de taille généralement croissante vers le centre alors que les bords sont lisses et plans. Les faces adradiales des supéromarginales du bras sont dièdre, traduisant une alternance des deux rangés de plaques. Les faces latérales, planes, sont bordées par une marge épaissie externe. La face interne est oblique et concave. Les inféromarginales interradiales ont un profil externe régulièrement convexe, proche d'un quart de cercle et une face externe plane ornée de f.a.e denses et de taille homogène' (Villier, 2001, p. 586).

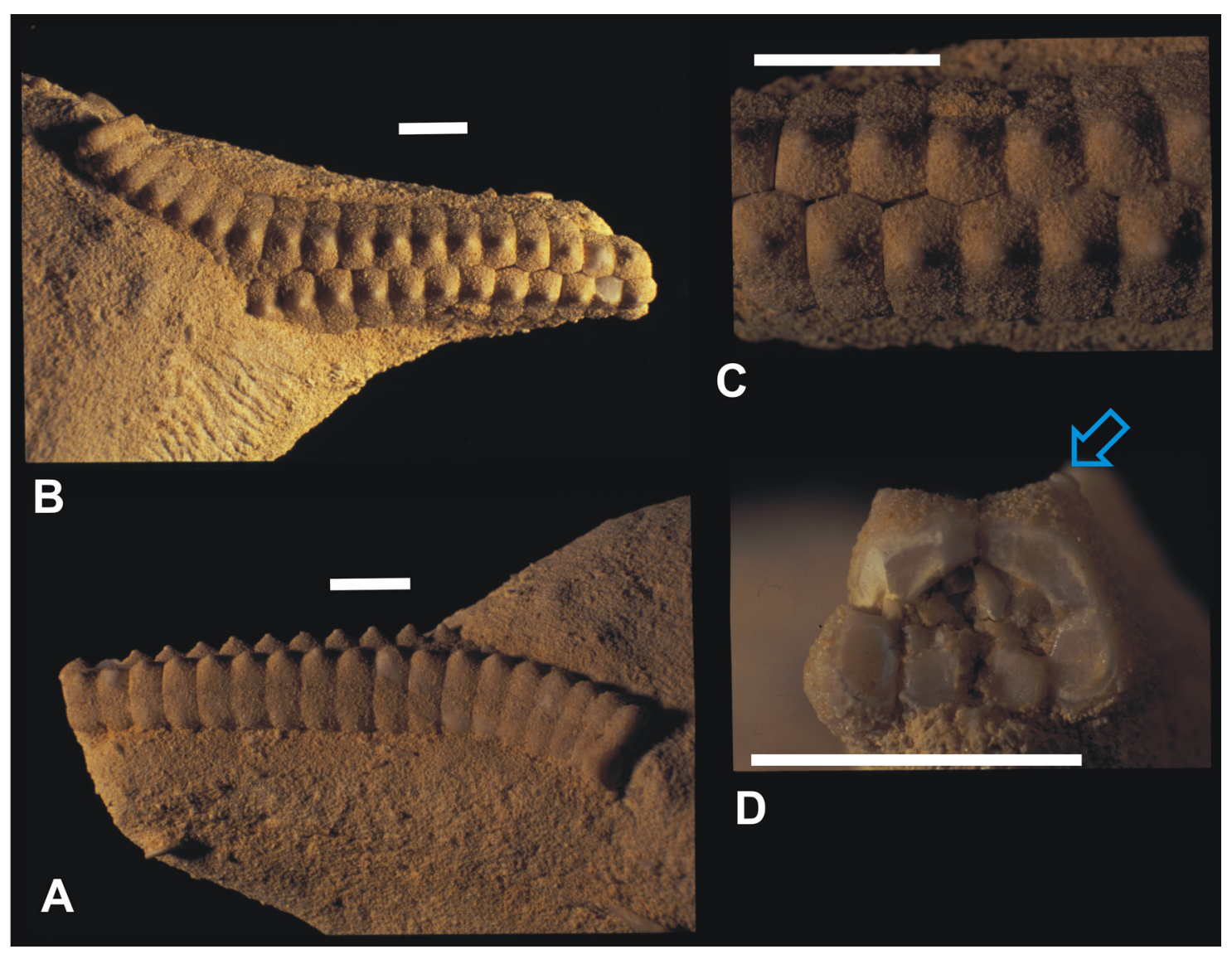

Figure 5 Chomataster breizh sp. nov. (paratype, NHMM van Rijsselt Collection, no. 100) from the lower Nekum Member (Maastricht Formation) at Eben Emael (CBR-Romontbos quarry). In $A$ and $B$, the broad, evenly rounded interradius is seen; in $C$ and $D$, the proximal portion of an arm is shown with regular alternation between superomarginals, and a cross-sectional view of the arm, with preserved superomarginal spine (arrow), stout and quadrangular adambulacrals and relatively sturdy and small ambulacrals. Scale bars equal 10 $\mathrm{mm}$. 
Discussion: This form can be differentiated from both Ch. acules and Ch. breizh sp. nov. in having stouter marginal ossicles with evenly rounded lateral and aboral surfaces and two spine pits on distal SMs.

Genus Nymphaster Sladen, 1889

Type species: Nymphaster protentus Sladen, 1889, p. 294, by subsequent designation of Fisher (1919).

Diagnosis: Arms long, narrow, well demarcated from disc; superomarginals meet over mid-radial line; aboral ossicles tall, polygonal, aboral, marginal and oral intermediate ossicles possess covering of granular or short conical spines; internal reinforcing aboral ossicles absent; pedicellariae attachment areas consist of central oval cavity with raised rim, flanked by 2 elongated triangular grooves (Gale, 1987b, p. 153).

\section{Nymphaster mudzborgh sp. nov.}

\section{Figure 7}

u r n : ls id: z o o b a n k. org : a c t: 8 C 0 C B43F-0FBD-41BE-B325-ED6C551EBA0A

Nymphaster sp.; Jagt (2000), p. 417, pl. 13, figs 5, 6. Pentasteria sp. 1?; Helm and Frerichs (2013), p. 192, fig. 1. Pentasteria sp. 2?; Helm and Frerichs (2013), p. 193, fig. 2. Nymphaster obtusus (Forbes, 1848) var. nov.; Neumann et al. (2021), fig. 25A, B.

Types: The holotype is NHMM JJ 16375a, an isolated 'angle' SM (SM3); paratypes are NHMM JJ 16375b (SM), NHMM JJ 16375c (IM) and NHMM JJ 16375d (IM).

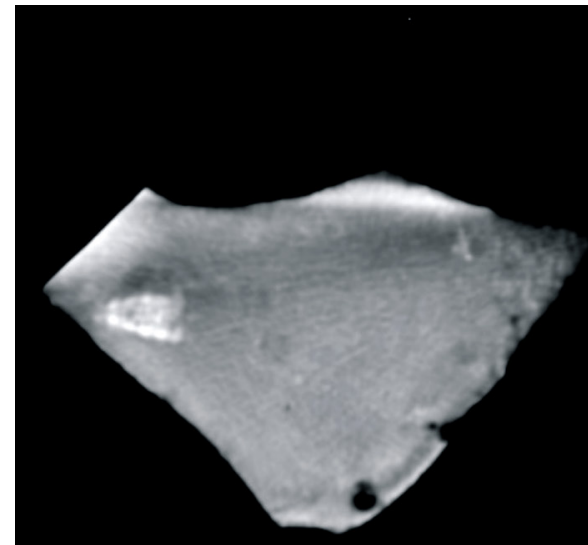

$\mathbf{A}$

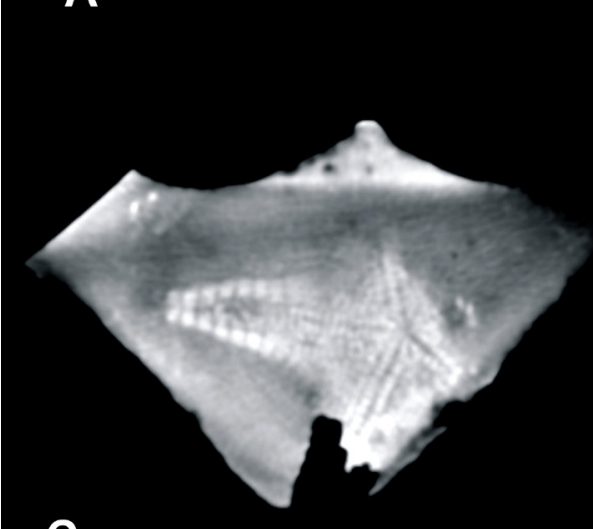

C

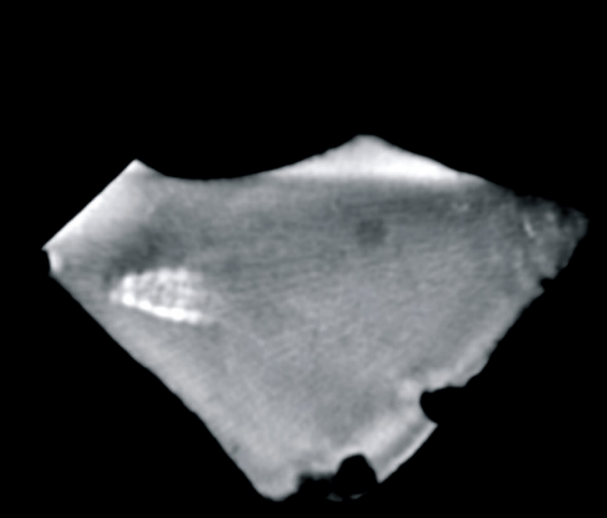

B

Figure 6 Chomataster breizh sp. nov. preliminary CT scans of the flint nodule containing the paratype (NHMM van Rijsselt Collection, no. 100) (see Figures 4-5). 
Type locality and horizon: Holcim quarry, Höver (Hannover area, Lower Saxony, Germany), pilula Zone (lower Campanian).

Derivation of name: Mudzborgh, here used in apposition, is the Mediaeval name of the modern Misburg in the Hannover agglomeration, close to which the Holcim and HeidelbergCement quarries are located (https://de.wikipedia.org/ wiki/Misburg-Anderten; accessed February 24, 2021).

Diagnosis: Small-sized species, known only from isolated marginal ossicles, $4-5 \mathrm{~mm}$ in length and 7.5-9.5 mm in width; central aboral surface in SMs raised, with granule pits of varying size, as well as 2-4 larger, crater-shaped spine pits, arranged in a more or less regular row; IMs angular, with inclined lateral face and covered in granule pits only.
Description of holotype: 'Angle' SM, 9.3 $\mathrm{mm}$ and $4.8 \mathrm{~mm}$ in width, with raised aboral surface (Figure 7E) and 3 large, crater-shaped spine pits, arranged in a row and set amongst variously sized granule pits. Intermarginal surface (Figure 7F) slightly sunken and with clusters of granules.

Paratype additions: Distal SM (Figures 7A and 7B) with two smaller and two larger spine pits; one of the latter situated on lateral surface. Two IMs (Figure 7C, D, G, H) with angular transition between lateral and oral surfaces and with even cover of granule pits only.

Discussion: This form differs consistently from $\mathcal{N}$. obtusus, which ranges from the middle Turonian to the lower Campanian, but is common only in the Offaster pilula Zone (lower Campanian) of southern England and northern France (Picardie) (Gale, 1987b), by its clearly raised abo-

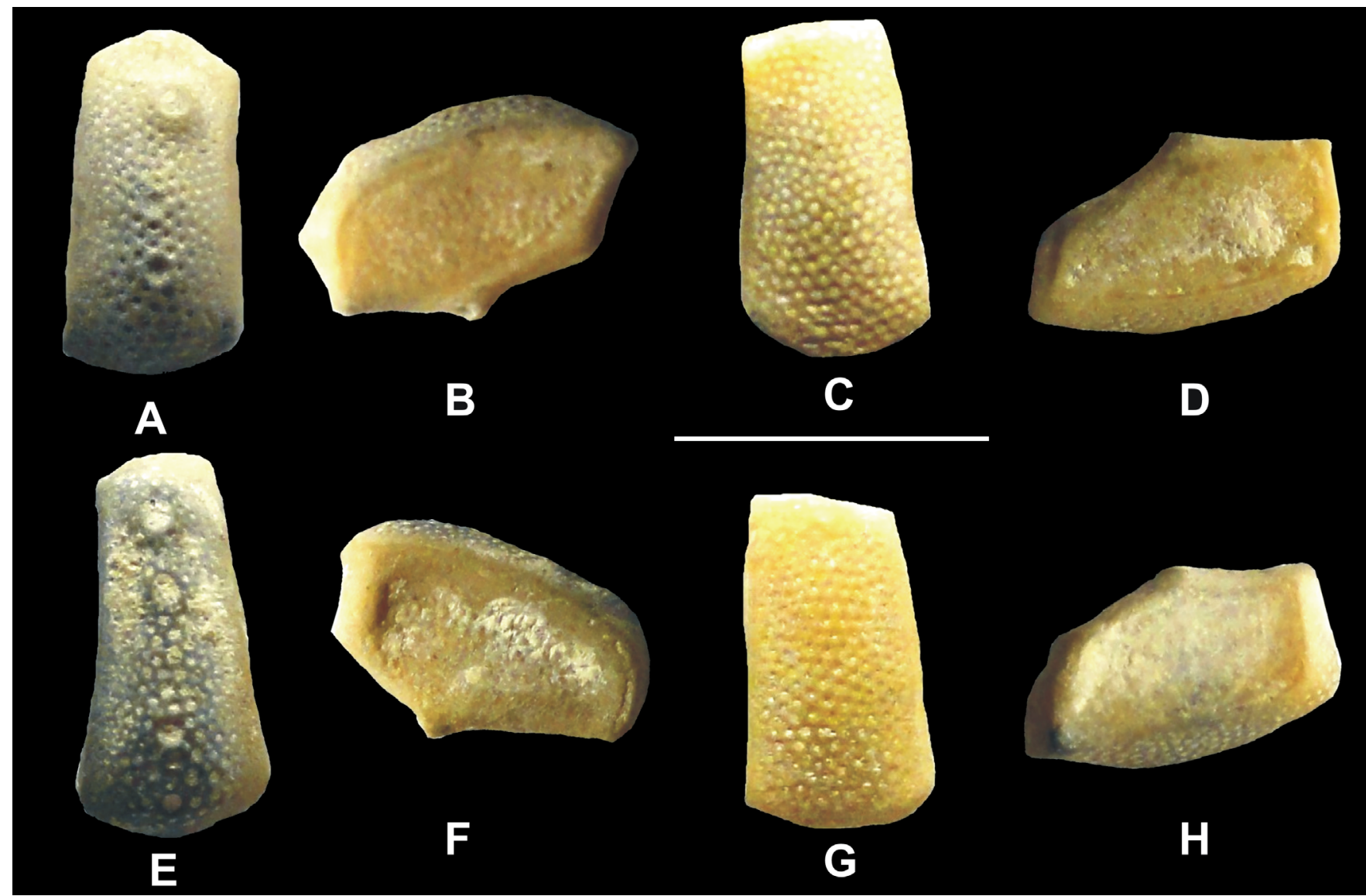

Figure 7 Nymphaster mudzborgh sp. nov. from the lower Campanian (pilula Zone) at Holcim-Höver quarry (Hannover area, northern Germany); isolated SMs and IMs in aboral view and in profile. A, B. Distal SM (paratype, NHMM JJ 16375b). C, D. Median IM (paratype, NHMM JJ 16375c). E, F. SM3 ('angle' SM) (holotype, NHMM JJ 16375a). G, H. Median IM (paratype, NHMM 16375d). Scale bar equals 10 mm. 
ral and oral surfaces and development of 3-5 large, crater-shaped spine bases, arranged in a row and set amidst a dense cover of granule pits of various sizes. IMs have a rather angular profile (transition lateral/oral surface). Proximal and distal marginal facets bear granules. We have seen material from the lower Campanian (pilula and pilula/senonensis zones) and upper Campanian (vulgaris Zone [= vulgaris/ basiplana Zone, vulgaris/stolleyi Zone] at the HolcimHöver and Misburg-Anderten (HeidelbergCement) quarries, respectively (no. 3 in Figure 1A). Material comparable in age with the latter record is known from the Liège-Limburg Basin (Jagt, 2000).

\section{Conclusions}

The genus Chomataster, as here interpreted, now comprises two species, the type Ch. acules Spencer, 1913 and Ch. breizh sp. nov. A third form, Nymphaster tethysiensis Villier, 2001, may also belong here; it is here transferred to Chomataster, albeit with a query. Contrary to Niebuhr and Seibertz (2016, p. 128), who assigned Goniaster (Astrogonium) coombii Forbes, 1848 to Chomataster, that species is here retained in Nymphaster (compare Gale, 1987b; Breton, 1992b). Chomataster breizh sp. nov., which ranges at least from the upper upper Campanian to the upper Maastrichtian, and is based on two articulated individuals, appears to overlap with Ch. acules, but it can be distinguished from that species by the lack of large, crater-shaped spine pits on median SMs and on all IMs. On the basis of isolated marginal ossicles, Nymphaster mudzborgh sp. nov. is erected. This is closely related to $\mathcal{N}$. obtusus (Forbes, 1848), but differs consistently by developing large spine pits on the lateral and aboral surfaces of SMs and in having IMs with an angular profile. This form appears to have survived into the upper Campanian of the Hannover area and the Liège-Limburg Basin.

\section{Acknowledgements}

For assistance in various ways, we wish to thank Ger Cremers, Edwin Defour, Rudi W. Dortangs,
Andy S. Gale, Peter Girod, Theo Geussens, Ludo Indeherberge, Roland Meuris, Willy van Rijsselt, Christian Schneider, Anne S. Schulp and Victor Strijbos. We are grateful to laboratory staff at AZM (Maastricht Academic Hospital) for preliminary CT scans and the journal reviewers, Prof. Andrew S. Gale (University of Portsmouth, Portsmouth, England) and Dr Christian Neumann (Museum für Naturkunde, Berlin, Germany) for their pertinent comments on an earlier version of the typescript.

\section{References}

Andrew, C., Gale, A.S., Howe, P., Paul, C.R.C., 2015, A new species of goniasterid starfish from chert in the Upper Greensand Formation (Lower Cretaceous, Albian) of Lyme Regis, Dorset, UK: Geoscience in South-West England, 13, 371-376.

Blainville, H.M.D. de, 1830, Dictionnaire des Sciences naturelles, suivi d'une biographie des plus célèbres naturalistes par plusieurs professeurs du Jardin du Roi, et des principales écoles. Zoophytes: Paris, Levrault, 546 p.

Breton, G., 1979, Les astéries du Crétacé de Normandie: Bulletin trimestriel de la Société géologique de Normandie et des Amis du Muséum du Havre, 65 (4), 5-87.

Breton, G., 1981, Metopaster meudonensis Cottreau, 1937, astérie du Campanien terminal du Bassin de Paris: Bulletin trimestriel de la Société géologique de Normandie et des Amis du Muséum du Havre, 67 (4), 21-30.

Breton, G., 1984, Comptoniaster, gen. nov. de Goniasteridae du Mésozoïque: Symbioses, 15 (4), 244-245.

Breton, G., 1985, Valettaster? Sphaerasteridae mésozoïque: Bulletin trimestriel de la Société géologique de Normandie et des Amis du Muséum du Havre, $72(1-2), 91-99$.

Breton, G., 1986, Découverte d'un juvenile de? Crateraster quinqueloba (Goniasteridae, Stelleroidea) dans la craie campanienne du Bassin de Paris: Bulletin trimestriel de la Société géologique de Normandie et des Amis du Muséum du Havre, 73 (3), 29-32. 
Breton, G., 1987, Metopaster uncatus et Chomataster aff. coombii: deux spécimens bien conservés de Goniasteridae (Asteroidae [sic], Echinodermata) du Sénonien d'Eure-et-Loir: Bulletin de la Société des Amis du Muséum de Chartres et des Naturalistes d'Eure-et-Loir, 7, 6-14.

Breton, G., 1988a, Description d'espèces nouvelles de Goniasteridae (Asteroidea, Echinodermata) du Crétacé de France: Bulletin trimestriel de la Société géologique de Normandie et des Amis du Muséum du Havre, 75 (1), 9-40.

Breton, G., 1988b, Pycinaster magnificus Spencer, 1913 (Echinodermata, Asteroidea): conservation proposée pour le nom spécifique [Case 2454]: Bulletin of zoological Nomenclature, 45 (2), 125-126.

Breton, G., 1992a, Réexamen de l'holotype de Pentaceros dilatatus Meunier, 1906 [= Nymphaster obtusus (Forbes, 1848)], Goniasteridae (Asteroidea, Echinodermata), Crétacé supérieur du Bassin de Paris: Bulletin du Muséum national d'Histoire naturelle de Paris, 4(14), 267-273.

Breton, G., 1992b, Les Goniasteridae (Asteroidea, Echinodermata) jurassiques et crétacés de France. Taphonomie, systématique, biostratigraphie, paléobiogéographie, évolution: Bulletin de la Société géologique de Normandie et des Amis du Muséum du Havre, Hors-série, Supplement, 78 (4), 1-590.

Breton, G., 1995a, La forme du corps de Crateraster debrisi Breton, 1992 (Asteroidea, Goniasteridae): Bulletin trimestriel de la Société géologique de Normandie et des Amis du Muséum du Havre, 82 (3), 51-53.

Breton, G., 1995b, Tethyaster guerangeri sp. nov. (Astropectinidae, Asteroidea, Echinodermata): deux spécimens d'astérides d'une conservation exceptionelle du Cénomanien du Mans (Sarthe, France): Bulletin trimestriel de la Société géologique de Normandie et des Amis du Muséum du Havre, 82 (4), 17-29.

Breton, G., 1996, Les pédicellaires alvéolaires sont-ils arrivés chez les Goniasteridae (Echinodermata: Asteroidea) au Crétacé par voie épidémique?: Bulletin de la Société zoologique de France, 121 (1), 87-92.
Breton, G., 1997a, Deux étoiles de mer du Bajocien du nord-est du Bassin de Paris (France): leurs alliés actuels sont des fossiles vivants: Bulletin trimestriel de la Société géologique de Normandie et des Amis du Muséum du Havre, 84 (1), 23-34.

Breton, G., 1997b, Patterns and processes of heterochrony in Mesozoic goniasterid seastars: Lethaia, 30, 135-144. https://doi. org/10.1111/j.1502-3931.1997.tb00454.x

Breton, G., Bilotte, M., Sigro, G., 1995, Dipsacaster jadeti sp. nov., Astropectinidae (Asteroidea, Echinodermata) du Maastrichtien des Petites Pyrénées (France): Bulletin trimestriel de la Société géologique de Normandie et des Amis du Muséum du Havre, 82 (4), 35-42.

Breton, G., Boullier, A., 2001, Regards croisés sur les modalités et processus évolutifs chez les astérides et chez les brachiopodes mésozoïques: Annales du Muséum du Havre, 67, 15-19.

Breton, G., Bourseau, J.-P., Bernier, P., Barale, G., Buffetaut, E., Gaillard, C., Gall, J.-C., Wenz, S., 1994, Les astérides (Asteroidea, Echinodermata) des calcaires lithographiques kimméridgiens de Cerin (Ain, France): Geobios, Mémoire spécial, 16, 49-60. https://doi.org/10.1016/s00166995(94)80020-0

Breton, G., Decombe, V., 1997, Comparaison des faunes d'astérides de deux gisements cénomaniennes de Basse-Normandie (France) et du Devon (Angleterre): Bulletin trimestriel de la Société géologique de Normandie et des Amis du Muséum du Havre, 84 (1), 9-11.

Breton, G., Ferré, B., 1995, Première observation d'éléments squelettiques d'Asteriidae (Asteroidea, Echinodermata) dans les craies du Cénomanien au Coniacien du Bassin de Paris: Revue de Micropaléontologie, 38 (4), 299-309.

Breton, G., Néraudeau, D., 2008, Nouveaux astérides cénomaniensetturoniensdeCharente-Maritime (SO France): Geobios, 41, 321-339. https:// doi.org/10.1016/j.geobios.2007.07.003

Breton, G., Vizcaïno, D., 1997, Astérides (Echinodermata) de l'Ilerdien (Yprésien) des Corbières (Aude, France): systématique, relations paléobiogéographiques et évolutives: 
Bulletin de la Société d'Études scientifiques de l'Aude, 97, 11-28.

Brünnich Nielsen, K., 1943, The asteroids of the Senonian and Danian deposits of Denmark [Opus posthumum edited by Th. Mortensen and Alfred Rosenkrantz]: Det Kongelige Danske Videnskabernes Selskab, Biologiske Skrifter, (2)5, 3-68.

Christensen, W.K., 1995, Belemnitella from the Upper Campanian and Lower Maastrichtian chalk of Norfolk, England: Special Papers in Palaeontology, 51, 1-84.

Christensen, W.K., 1999, Upper Campanian and Lower Maastrichtian belemnites from the Mons Basin, Belgium: Bulletin de l'Institut royal des Sciences naturelles de Belgique, Sciences de la Terre, 69, 97-131.

Ernst, G., 1972, Grundlagen der Stammesgeschichte bei irregulären Echiniden der nordwesteuropäischen Oberkreide: Geologisches Jahrbuch, A4, 61-175.

Fisher, W.K., 1919, Starfishes of the Philippine seas and adjacent waters: Bulletin of the United States National Museum, 100 (3 volumes), 1-712.

Forbes, E., 1841, A history of British starfishes and other animals of the class Echinodermata: London, John van Voorst, 276 p. https://doi. org/10.5962/bhl.title.2129

Forbes, E., 1848, On the Asteriadæ found fossil in British strata: Memoirs of the Geological Survey of Great Britain, (2) 2, 457-482.

Gale, A.S., 1987a, Goniasteridae (Asteroidea, Echinodermata) from the Late Cretaceous of north-west Europe. 1. Introduction. The genera Metopaster and Recurvaster: Mesozoic Research, 1 (1), 1-69.

Gale, A.S., 1987b, Goniasteridae (Asteroidea, Echinodermata) from the Late Cretaceous of north-west Europe. 2. The Genera Calliderma, Crateraster, Nymphaster and Chomataster: Mesozoic Research, 1 (4), 151-186.

Gale, A.S., 1987c, Phylogeny and classification of the Asteroidea (Echinodermata): Zoological Journal of the Linnean Society London, 89, 107-132. https://doi.org/10.1111/j.1096-3642.1987. tb00652.x
Gale, A.S., 1989, Migration and evolution in Late Cretaceous Goniasteridae (Asteroidea, Echinodermata) from north-west Europe: Proceedings of the Geologists' Association, 100, 281-291. https://doi.org/10.1016/ s0016-7878(89)80048-3

Geinitz, H.B., 1872, Seeschwämme, Korallen, Seeigel, Seesterne und Haarsterne, in Geinitz, H.B., Das Elbthalgebirge in Sachsen. Zweiter Theil. Der mittlere und obere Quader: Palaeontographica, 20(7), 1-19.

Gray, J.E., 1847, Descriptions of some new genera and species of Asteriadae: Proceedings of the Zoological Society of London, 15, 73-83.

Helm, C., Frerichs, U., 2013, Seesterne (Asteroidea), in Fossilien aus dem Campan Hannovers, 3. Komplett überarbeitete Auflage, 192200: Hannover, Arbeitskreis Paläontologie Hannover.

Indeherberge, L., Defour, E., Van der Ham, R., Jagt, J.W.M., 1999, What is Micraster ciplyensis Schlüter, 1897? (Late Cretaceous echinoids), in Candia Carnevali, M.D., Bonasoro, F.(eds.), Echinoderm Research 1998. Proceedings of the Fifth European Echinoderm Conference on Echinoderms, Milan-Italy, 7-12 September 1998, Rotterdam-Brookfield: A.A. Balkema.

Jagt, J.W.M., 1999, Late Cretaceous-Early Palaeogene echinoderms and the $\mathrm{K} / \mathrm{T}$ boundary in the southeast Netherlands and northeast Belgium Part 1: Introduction and stratigraphy: Scripta Geologica, 116, 1-57.

Jagt, J.W.M., 2000, Late Cretaceous-Early Palaeogene echinoderms and the $\mathrm{K} / \mathrm{T}$ boundary in the southeast Netherlands and northeast Belgium - Part 5: Asteroids: Scripta Geologica, 121, 377-503.

Jagt, J.W.M., 2002, Neues zum Thema Chomataster acules Spencer, 1913 (Asteroidea; Oberkreide, Europa), in 2. Treffen deutschsprachiger Echinodermologen, Programm und Abstracts [Museum für Naturkunde, HumboldtUniversität zu Berlin], 12-13.

Jagt,J.W.M., 2010, The asteroid Chomataster acules Spencer, 1913 from the upper Maastrichtian of northeast Belgium - pure frustration, despite perfect 
preservation, in Reich, M., Reitner, J., Roden, V., Thuy, B. (eds.), Echinoderm Research 2010. 7th European Conference on Echinoderms, Göttingen, October 2-9, 2010, Abstract Volume and Field Guide to Excursions, 57-58. Göttingen: Universitätsdrucke Göttingen.

Jagt, J.W.M., 2015, Additional data on Chomataster acules Spencer, 1913 (Asteroidea) from the Maastrichtian type area (Late Cretaceous, northeast Belgium), in Sovremennye Problemy Paleontologii. Materialy LXI Sessiia Paleontologicheskgo Obshchestva, 13-17 aprelia, Sankt-Petersburg, 135.

Jagt, J.W.M., Jagt-Yazykova, E.A., 2012, Stratigraphy of the type Maastrichtian - a synthesis, in Jagt, J.W.M., Donovan, S.K., Jagt-Yazykova, E.A. (eds.), Fossils of the type Maastrichtian (Part 1): Scripta Geologica Special Issue, 8, 5-32.

Jagt, J.W.M., Jagt-Yazykova, E.A., 2018, Stratigraphical ranges of tegulated inoceramid bivalves in the type area of the Maastrichtian Stage (Belgium, the Netherlands), in Jagt-Yazykova, E.A., Jagt, J.W.M., Mortimore, R.N. (eds.), Advances in Cretaceous palaeontology and stratigraphy Christopher John Wood Memorial Volume: Cretaceous Research, 87, 385-394. https://doi. org/10.1016/j.cretres.2017.05.022

Jagt, J.W.M., Savelsbergh, J., Gale, A.S., 1994, Presentation of a near-complete early Palaeocene specimen of Chomataster acules Spencer, 1913 (Asteroidea) from NE Belgium, in David, B., Guille, A., Féral, J.P., Roux, M. (eds.), Echinoderms through Time. Proceedings of the Eighth International Echinoderm Conference, Dijon, France, 6-10 September 1993: 318. A.A. Balkema (Rotterdam-Brookfield).

Jagt, J.W.M., Van Bakel, B.W.M., Deckers, M.J.M., Donovan, S.K., Fraaije, R.H.B., Jagt-Yazykova, E.A., Laffineur, J., Nieuwenhuis, E., Thijs, B., 2018, Late Cretaceous echinoderm 'odds and ends' from the Low Countries: Contemporary Trends in Geosciences, 7, 255-282. https://doi. org/10.2478ctg-2018-0018.pdf (us.edu.pl)

Jeletzky, J.A., 1951, Die Stratigraphie und Belemnitenfauna des Obercampan und Maastricht Westfalens, Nordwestdeutschlands und Dänemarks, sowie einige allgemeine Gliederungs-Probleme der jüngeren borealen Oberkreide Eurasiens: Beihefte zum Geologischen Jahrbuch, 142 p.

Kennedy, W.J., 1993, Campanian and Maastrichtian ammonites from the Mons Basin and adjacent areas (Belgium): Bulletin de l'Institut royal des Sciences naturelles de Belgique Sciences de la Terre, 63, 99-131.

Keutgen, N., 2011, The belemnite zonation of the uppermost Cretaceous in the MaastrichtAachen-Liège, Brabant-Méhaigne and Mons areas (Belgium, southeast Netherlands), in Jagt, J.W.M., Jagt-Yazykova, E.A., Schins, W.J.H. (eds.), A tribute to the late Felder brothers - pioneers of Limburg geology and prehistoric archaeology: Netherlands Journal of Geosciences, 90, 165-178.

Keutgen, N., 2018, A bioclast-based astronomical timescale for the Maastrichtian in the type area (southeast Netherlands, northeast Belgium) and stratigraphic implications: the legacy of P.J. Felder: Netherlands Journal of Geosciences, 97, 229-260. https://doi.org/10.1017/ njg.2018.15

Lambert, J., 1901, Essai d'une monographie du genre Micraster et notes sur quelques échinides. Errata et addenda, in de Grossouvre, A. (ed.), Recherches sur la Graie supérieure: Mémoires du Service de la Carte géologique de France, (3) 23, 957-971.

Lambert,J., 1911, Description des Échinides crétacés de la Belgique principalement de ceux conservés au Musée royal de Bruxelles. II. Échinides de l'étage Sénonien: Mémoires du Musée royal d'Histoire naturelle de Belgique, 4, 1-81.

Lewis, D.N., 1993, Catalogue of the type and figured specimens of fossil Asteroidea and Ophiuroidea in The Natural History Museum: Bulletin of the Natural History Museum (Geology), 49, 47-80. https://doi.org/10.5962/p.313805

Maryańska, T., Popiel-Barczyk, E., 1969, On the remains of Ophiuroidea from the uppermost Maastrichtian and Danian deposits at Nasiłów near Puławy, Poland: Prace Muzeum Ziemi, 14, 131-139. 
McNamara, K.J., 2011, The star-crossed stone. The secret life, myths, and history of a fascinating fossil: Chicago, The University of Chicago Press, 272 p. https://doi.org/10.7208/ chicago/9780226514710.001.0001

Müller, A.H., 1953, Die isolierten Skelettelemente der Asteroidea (Asterozoa) aus der obersenonen Schreibkreide von Rügen: Geologie, Beiheft, 8, $1-66$.

Néraudeau, D., Breton, G., 1993, Astérides du Cénomanien de Charente-Maritime (SW France): Geobios, 26, 105-120. https://doi. org/10.1016/s0016-6995(93)80011-f

Neugebauer, J., Ruhrmann, G., 1978, Experimentelle Karbonatzementation: syntaxialer Calcit auf Echinodermen: Neues Jahrbuch für Geologie und Paläontologie, Monatshefte, 9, 545-555.

Neumann, G., Jagt, J.W.M., Girod, P., Krupp, R., 202 1, Seesterne (Asteroidea), in Fossilien aus dem Campan Hannovers, 4. Auflage. Hannover: Arbeitskreis Paläontologie Hannover (in press).

Niebuhr, B., Seibertz, E., 2016, Asteroiden (Seesterne): Geologica Saxonica, 62, 113-141.

Niebuhr, B., Volkmann, R., Schönfeld, J., 1997, Das obercampane polyplocum-Event der Lehrter Westmulde (Oberkreide, N-Deutschland): Bio-Litho-Sequenzstratigraphie, FaziesEntwicklung und Korrelation: Freiberger Forschungshefte, C468, 211-243.

Orbigny, A.D. d'., 1850, Prodrome de paléontologie stratigraphique universelle des animaux mollusques et rayonnés : Paris, Masson, 427 p. https://doi.org/10.5962/bhl.title.62810

Peron, A., 1887, Notes pour servir à l'histoire du terrain de craie dans le sud-est du Bassin AngloParisien: Bulletin de la Société des Sciences historiques et naturelles de l'Yonne, 41, 145428.

Perrier, J.O.E., 1884, Mémoire sur les étoiles de mer recueillies dans la Mer d'Antilles et le Golfe de Mexique: Nouvelles Archives du Muséum d'Histoire naturelle de Paris, 6, 127-276. https://doi.org/10.5962/bhl.title.82184

Reich, M., Frenzel, P., 2002, Die Fauna und Flora der Rügener Schreibkreide (Maastrichtium,
Ostsee): Archiv für Geschiebekunde, 3 (2-4), 73-284.

Robaszynski, F., Christensen, W.K., 1989, The upper Campanian-Lower Maastrichtian chalks of the Mons basin, Belgium: a preliminary study of belemnites and foraminifera in the Harmignies and Ciply areas: Geologie en Mijnbouw, 68, 391-408.

Robaszynski, F., Dhondt, A.V., Jagt, J.W.M., 2002, Cretaceous lithostratigraphic units (Belgium), in Bultynck, P., Dejonghe, L. (eds.), Guide to a revised lithostratigraphic scale of Belgium: Geologica Belgica, 4 (1-2), 121-134. https:// doi.org/10.20341/gb.2014.049

Schlüter, G., 1897, Ueber einige exocyclische Echiniden der baltischen Kreide und deren Bett:Zeitschrift der deutschen geologischen Gesellschaft, 49 (1), $18-50$.

Schulz, M.G., Weitschat, W., 1971, Asteroideen aus der Schreibkreide von Lägerdorf (Holstein) und Hemmoor (N. Niedersachsen): Mitteilungen aus dem Geologisch-Paläontologischen Institut der Universität Hamburg, 40, 107-130.

Schulz, M.G., Weitschat, W., 1975, Phylogenie und Stratigraphie der Asteroiden der nordwestdeutschen Schreibkreide. Teil I: Metopaster/Recurvaster- und Calliderma/ Chomataster-Gruppe: Mitteilungen aus dem Geologisch-Paläontologischen Institut der Universität Hamburg, 44, 249-284.

Simon, E., 2000, Upper Campanian brachiopods from the Mons Basin (Hainaut, Belgium): the brachiopod assemblage from the Belemnitella mucronata Zone: Bulletin de l'Institut royal des Sciences naturelles de Belgique, Sciences de la Terre, 70, 129-160.

Simon, E., Owen, E.F., 2001, A first step in the evolution of the genus Cretirhynchia Pettitt, 1950: Bulletin de l'Institut royal des Sciences naturelles de Belgique, Sciences de la Terre, 71, 53-118.

Sladen, W.P., 1889, Report on the Asteroidea: Report on the Scientific Results of the Voyage of H.M.S. Challenger during the years 18731876, Zoology, 30 (part 51), 893 p.

Sladen, W.P., 1891, A monograph on the British fossil 
Echinodermata from the Cretaceous formations, Vol. II, the Asteroidea and Ophiuroidea: Monograph of the Palaeontographical Society London, 1-66. https://doi.org/10.1017/ cbo9781316146385.003

Smith, A.B., Wright, G.W., 2003, British Cretaceous echinoids, Part 7, Atelostomata, 1. Holasteroida: Monograph of the Palaeontographical Society London, 156 (619), 440-568.

Smith, A.B., Wright, G.W., 2012, British Cretaceous echinoids, Part 9, Atelostomata, 2. Spatangoida (2): Monograph of the Palaeontographical Society London, 166 (639), 635-754.. https:// doi.org/10.1002/gj.2497

Spencer, W.K., 1913, The evolution of the Cretaceous Asteroidea: Philosophical Transactions of Royal Society of London, B214, 99-177. https://doi.org/10.1098/rstb.1914.0004

Stokes, R.B., 1975, Royaumes et provinces fauniques du Crétacé établis sur la base d'une étude systématique du genre Micraster: Mémoires du Muséum national d'Histoire naturelle, Nouvelle série, C31, 94 p.

Villier, L., 2001, Systématique des Asteroidea (Echinodermata) du Campanien et du Maastrichtien de Tercis les Bains (Landes, France), in Odin, G.S. (ed.), The CampanianMaastrichtian Stage Boundary. Characterisation at Tercis les Bains (France) and correlation with Europe and other continents [Developments in Palaeontology and Stratigraphy, 19]:
Amsterdam, Elsevier. 582-611. https://doi. org/10.1016/s0920-5446(01)80056-x

Villier, L., Odin, G.S., 2001, Stratigraphie et écologie des astérides (Asteroidea, Echinodermata) du Campanien-Maastrichtien de Tercis les Bains (Landes, France), in Odin, G.S. (ed.), The Campanian-Maastrichtian Stage Boundary. Characterisation at Tercis les Bains (France) and correlation with Europe and other continents [Developments in Palaeontology and Stratigraphy, 19]: Amsterdam, Elsevier, 568-581. https://doi.org/10.1016/s09205446(01)80055-8

Villier, L., Breton, G., Margerie, P., Néraudeau, D., 2004, Manfredaster gen. nov. cariniferus sp. nov. un astéride original du Coniacien de SeineMaritime et révision systématique de la famille des Stauranderasteridae (Echinodermata, Asteroidea): Bulletin de la Société géologique de Normandie et des Amis du Muséum du Havre, 90, 29-41.

Wienberg Rasmussen, H., 1945, Observations on the asteroid fauna of the Danian: Meddelelser fra det dansk geologiske Forening, 10, 417-426.

Wienberg Rasmussen, H., 1950, Cretaceous Asteroidea and Ophiuroidea with special reference to the species found in Denmark: Danmarks Geologiske Undersøgelse, (2) 77, 1-134. https://doi.org/10.34194/raekke2.v77.6866

Woodward, S., 1833, An outline of the geology of Norfolk: London, Longman \& Co., 55 p. 